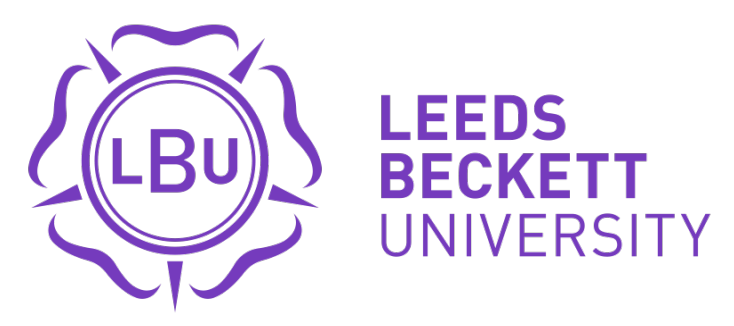

Citation:

Dowling, F and Flintoff, A (2015) A whitewashed curriculum? The construction of race in contemporary PE curriculum policy. Sport Education and Soceity. ISSN 1357-3322 DOI: https://doi.org/10.1080/13573322.2015.1122584

Link to Leeds Beckett Repository record:

https://eprints.leedsbeckett.ac.uk/id/eprint/4729/

Document Version:

Article (Accepted Version)

The aim of the Leeds Beckett Repository is to provide open access to our research, as required by funder policies and permitted by publishers and copyright law.

The Leeds Beckett repository holds a wide range of publications, each of which has been checked for copyright and the relevant embargo period has been applied by the Research Services team.

We operate on a standard take-down policy. If you are the author or publisher of an output and you would like it removed from the repository, please contact us and we will investigate on a case-by-case basis.

Each thesis in the repository has been cleared where necessary by the author for third party copyright. If you would like a thesis to be removed from the repository or believe there is an issue with copyright, please contact us on openaccess@leedsbeckett.ac.uk and we will investigate on a case-by-case basis. 


\section{A Whitewashed curriculum? The construction of race in contemporary PE curriculum policy}

Fiona Dowling and Anne Flintoff

Affiliations

Acknowledge grant from British Academy

Abstract

Analyses of curricula in a range of countries show how they tend to reinforce, rather than challenge, popular theories of racism. To date, we know little about the contribution of physical education (PE) curriculum policy to the overall policy landscape. This paper examines the construction of 'race' and racism in two national contexts (Norway and England) as a means of putting race and antiracism on the PE policy research agenda. It adopts a critical whiteness perspective to analyse how whiteness, as a system of privilege, contributes to the racialisation of valued knowledge in PE and asks, who potentially benefits and/or is marginalised within the learning spaces available in the texts? The discourse analysis reveals that three discursive techniques of whiteness combine to privilege 'white', Eurocentric knowledge content. Unmarked 'white' PE practices and students are constructed as universal, normative and contingent. As a result, non-white PE practices and students are positioned on the margins in contemporary policy texts. By revealing the racialization processes evident in the texts we aim to trouble the profession's taken-for-granted truths about 'race' in PE as integral to working towards the development of an antiracist subject.

\section{Key words}

Physical Education Policy, 'race', Antiracism, Whiteness, Discourse

\section{Introduction}

Education and schooling are recognised as important contexts for challenging racism, yet there is little evidence that race equality has enjoyed a central position in education policy during the past decades. Research of educational achievement shows how certain minoritised groups have experienced relatively severe educational inequalities (Bakken and Elstad, 2012; Gillborn, 2008). Reflecting upon the English context, Gillborn (2008) argues that policy makers in England have been more inclined to pander to the feelings and fears of White people rather than aim to eradicate racism. Analyses of curricula in a range of countries show how they tend to reinforce, rather than challenge, popular theories of racism (see, for 
example, in Norway Breilid, 2012; in Ireland Bryan, 2012; in USA Ladson Billings ??; in Australia ??). To date, we know little about the contribution of physical education (PE) curriculum policy to the overall policy landscape. This paper draws therefore upon selected policy documents in two national contexts as a means of putting race and racism on the PE policy research agenda. It critically examines the construction of 'race' and racism in a selection of formal documents. It addresses one aspect of a larger critical exploration of white physical educators' (teacher educators and PE teachers) perspectives on race and racism with the long-term aim of supporting them in critical engagement with race.

We believe there are a number of compelling arguments for why the PE profession needs to direct a gaze on 'race' and racism in the contemporary moment. Firstly, taken-for-granted, common sense views about the notion of race continue to circulate in PE and sport cultures (Azzarito and Harrison, 2008; Barker et al, 2014; Bruno Massao and Fasting, 2014; Fitzpatrick, 2013; Flintoff, 2014; Flintoff et al, 2014; Hylton, 2009, 2015; Harrison, Azzarito and Burden, 2004; McDonald, 2013; Moser, 2004; Spracklen, 2008). Teachers and students are ascribed particular traits, behaviours, and attitudes on the ill-founded concept that humans belong to different, distinct 'racial' groups of people. Integral to this discredited theory of racial difference is the idea that certain racial groups are superior to other subordinate racial groups, and in particular, that 'whiteness' signifies 'raceless', normalised identities against which 'black' identities are Othered (Frankenberg,1993). The workings of power at play is thus overlooked. Secondly, research undertaken to date has tended to focus on the minoritised Other (for example, Muslim girls) rather than the complexity of race relations and not least, the complicity of Whites in them. We share Evans (2014) view that physical educators sorely need to examine their/our culpability in the reproduction of PE as a predominately 'white' space. As Bryan (2012, citing Forman, 2004, p. 602) argues,

... failure to interrogate the multi-dimensionality of contemporary racism and the subtleties and dynamics of white supremacy supports the illusion of meritocracy, according to which different outcomes for racially minoritised groups can be 'explained' - not by racial discrimination - but by their cultural deficiencies, such as lack of motivation or 'ability'. 
Thirdly, following Apple (2004) and acknowledging that policy, as a fundamentally political issue, is central to understanding how power operates, we argue there has been little systematic analysis of the constructions of race in PE and sport policy. Certainly, Rossi et al's (2009) and McEvilly et al's (2014) policy studies both problematise the way in which official curricula, in respectively Australia and Scotland, gloss over and/or ignore students' socialeconomic and ethnic identities. Moreover, in the case of the Queensland syllabus, the research brings our attention to how PE content is "... culturally situated within the dominant forms of Australian sport ... in spite of Australia's claim to be a multicultural society" (Rossi et al 2009, p. 87). Yet, these themes have still to be explored in greater depth within PE research. It is only recently that some scholars have begun to embrace postcolonial lenses with which to deconstruct the legacies of Eurocentric thought (for example, McDonald et al, 2009; Sykes 2014). The latter appears problematic given current global mass migration patterns and the increasing diversity of classrooms, not least in a climate marked by the mobilising of fear around the stranger and increasing xenophobia and islamophobia (Arnot, 2014). As critical pedagogues, we are concerned about questions of how the predominantly white PE teaching profession (Douglas and Halas, 2011) can construct ethnically inclusive, social democratic learning spaces in PE and whether the profession has been sufficiently critical of Eurocentric thought that underpins what counts as legitimate PE knowledge. More specifically in this paper, we use our own policy contexts and adopt a critical whiteness lens (Frankenberg 1993) in order to ask, 'what constructions of race do they contain and what are the consequences, for whom?' Ultimately, our research aims to begin to understand the discourses or 'truths' about race traceable in PE policy as a starting point for developing antiracist PE.

Below we start by discussing why a critical whiteness perspective is appropriate for studying the construction of race and ethnicity in PE policy texts and provide a brief overview of our understanding of policy as text and discourse (Ball, 1993). We follow this up with a short summary of the ways in which 'race' have been constructed in education policy during the past 60 years. We describe the methodological approach we have adopted and thereafter present some examples from policy documents in England/Wales and Norway and discuss these in the light of an antiracist PE.

\section{A critical whiteness perspective}


Indeed, when we adopt a critical whiteness lens it is imperative to conceptualise this approach as a contribution to anti-racism and a means for critiquing existing power relations. Cognisant of the dangers of seeming to reify “ "... white as a race with an essential cultural core and collective destiny" (Garner 2007, p.2), we underscore that it is a theoretical position that acknowledges the shortcomings of previous race inequality perspectives. The latter have tended to focus on the inadequacies of Others or have focused upon the race relations between 'us and them', rather than examining whiteness as a system of privilege. In other words, it shifts the researcher's gaze onto the majority dominant group. Garner (2007, p.5) cites Hartigan (2005, p. 1) who claims that:

Whiteness asserts the obvious and overlooked fact that whites are racially interested and motivated. Whiteness both names and critiques hegemonic beliefs and practices that designate white people as 'normal' and racially 'unmarked'.

Understanding whiteness as a racial discourse, it is possible therefore to explore how white cultural practices, as expressed in the Norwegian and English national PE curricula and surrounding policy texts, promote a certain racial hierarchy and distribute embodied capital and rights.

Whiteness offers a frame for understanding social relationships and making explicit how white identities are racialised; it enables us to examine power at work in the social and political processes through which racially distinct groups are constituted and become meaningful in given contexts (Garner, 2010). It offers, in other words, the means to study how the idea of race and racial groups are socially constructed and how race becomes an important factor in the distribution of social resources, at the intersections of the structures of gender, sexuality and social class. Central to the notion of whiteness is the recognition that as an identity it only exists in relation to other racialised identities and its meaning is not fixed, but context-dependent (for example, in relation to ideas about the nation and geopolitical and socio-historical boundaries). Whiteness as a marker is thus a racialised identity like any other, such as Asian, Black, African-American, but crucially it is "unlike any other, because it is the dominant, normalised location" (Garner, 2007, p.6). White privilege is, nevertheless, not necessarily experienced or distributed equally. In Norway, for example, the Sami have historically been, and some would argue continue to be, awarded lower status and access to resources than ethnic Norwegians (Gullestad, 2006). Another crucial aspect of a critical 
whiteness lens is an acknowledgement of its seeming invisibility (Dyer 1997; hooks, 1997): white is an unmarked, dominant and normative space against which difference is constructed. Closely tied up with the dominance of European Enlightenment thought and imperial power via processes of colonialism and neo-colonialism, whiteness is often perceived as representing humanness, normality and universality (Dyer, 1997; Garner, 2007; Gullestad, 2006). As Garner (2007, p. 35) writes, "Whiteness is rendered invisible under the weight of accumulated privileges". To summarise, following Frankenberg (1997, pp.1-2), we believe that critical attention to whiteness in PE policy "... offers a ground not only for the examination of white selves (who may indeed be white others, depending on the position of the speaker) but also for the excavation of the foundations of all racial and cultural positionings".

\section{Policy as text and discourse}

Turning to how we conceptualise policy in this discussion, we adopt Ball's (1993) distinction between policy as text and discourse. In so doing, we acknowledge that the PE curriculum is not simply an object, a written text expressing values and ideas about appropriate learning content, but the discourses evident in the text do things to people. Physical educators' readings and interpretations of a text lead to processes and outcomes in the PE classroom. We also recognise that the values and interests expressed in policy documents represent struggles, compromises and interpretations: there are multiple positions in any one policy. Similarly, the decoding and interpretation of PE- and core curricula, are inevitably complex, or what Ball, Maguire and Braun (2012) describe as a hybrid process of enactment, suffused with emotions and saturated by power. As well as focusing upon the ideas that are expressed, we are equally interested in identifying what appears to have been overlooked (Ball, 1993; Penney and Evans 1999).

We recognise that each reader of policy is differently situated and has biographical experiences, skills, and resources that frame her/his interpretation. Policies can change, but we also know that practice can seemingly remain the same. The crucial point is that policies are acted on in some way. Analysing policy as discourse, we can examine the production of 'truths' and 'knowledges': the ways in which the meaning and the use of propositions and words create certain possibilities for thought and action. For example, how the PE curriculum 
as text enables students with different ethnic backgrounds to adopt different subjectivities, some of whom enjoy greater authority than others. As Ball (1993:14) writes, "Discourses are about what can be said, and thought, but also about who can speak, when, where and with what authority." In terms of PE, we can extend this definition to include the 'whats' and 'whos' of movement and embodiment. What physical activity practices/sports are valued? Who benefits from the learning spaces created via the texts of the PE curriculum? Whose bodies are revered, whose are scorned?

We also acknowledge that in trying to grasp an understanding of current policy it is necessary to analyse the ways in which wider debates about race, education or physical education/sport in society feed into the texts themselves and equally how they influence interpretations of them (Gillburn, 2008). For instance, recent incidents of terror in both Norway and England have fuelled public debate about the Other, as has the recent mass migration of refugees to Europe. In sport, on-going media coverage of racism on the football terraces feeds for example into the psyche of 'racial equality'. Furthermore, central to analysis of contemporary policy is attention to how

"... policy embodies strong continuities with the past while it simultaneously reshapes contemporary priorities, actions and beliefs. The combination of old and new is always complex and always changing. It is simply wrong to imagine that nothing changes but it is naive to think that each new policy statement represents a fresh start or a new chapter untouched by centuries of prior actions and assumptions" (Gillborn, 2008, p. $71)$.

\section{'Race' in education policy}

Heeding the need to pay attention to the socio-historical aspects of the construction of 'race' in education policy, our analysis of 'race' in contemporary PE policy must be contextualised within national policy maps. Despite the countries very different histories, not least with regard to immigration, there are a number of similarities and overlapping trends. Notwithstanding the dangers of oversimplifying phases in the post-war period, because as Gillborn (2008) reminds us, there are often competing views at one and the same time, in England he summarises the following phases and themes: ignorance and neglect from 1945- 
late 1950s; assimilation from late 1950s to late 1960s; integration (assimilation by a new name) 1966-to late 1970s; cultural pluralism and multiculturalism from late 1970s to mid1980s; Thaterism: The New racism and colour-blind policy from mid-1980s to 1997; naive multiculuralism: New Labour and the Blairite project (1997-2001); cynical multiculturalism from 2001-2005; and aggressive majoritarianism (2005 - present). In Norway, the White Paper, 'Diversity and mastery' (NOU 2010:7) describes the following phases and themes: assimilation from the 1950s to mid-1980s; integration (1987-2000); and multiculturalism from 2000 onwards (tinged with conservative overtones from 2006). In other words, in both countries policy rests/has rested upon ideas associated with pluralism, antiracism and equity on the one hand and antipluralist, racist and anti-immigrant on the other hand (Gillborn 2008).

\section{Methodology}

From our critical race theory and whiteness perspective, we have selected a purposeful sample (Patton, 1990) of contemporary PE policy texts in England and Norway, including national core curricula, PE subject curricula, examinable PE syllabi, and school sport policy (see table 1). Recognising the 'crowded policy spaces' of PE and school sport in England (Houlihan, 2000; Jung, Pope and Kirk, 2015) and of school PE/sport/physical activity in Norway (Kårhus, in press), inevitably we have some omissions. The selection of documents also reflects the fact that in Norway youth sport is organised under the auspices of the Norwegian Sports Federation, rather than in schools, as is the case in England. We have therefore concentrated most of our attention on subject curricula for mandatory PE, as well as the increasingly popular forms of examinable PE.

By contrasting two national contexts, we aim to demonstrate the contextual constraints of constructions of 'race' in policy documents, whilst simultaneously seeking commonalities across national boundaries. England's imperial history and its relatively well-established status as a multiethnic society (with large scale immigration since1945) contrasts with Norway's recent independence as a nation state (achieved in 1905 following the dissolution of the union with Sweden, preceded by 400 years' of Danish rule) and its' recent (from 1970s), relatively restrictive policy of immigration (Gullestad, 2006). With regard to schooling, education in Norway remains a central feature of the welfare state, centrally steered by a 
national curriculum with a 200-year history, though like in many countries, it has been strongly influenced by global neoliberalist education policy in the past few decades (Karlsen, 2002). In England, on the other hand, the very notion of a 'national' curriculum can be perceived as something of a misnomer given the increase in the number of academies/free schools (57\% of state-funded schools educating $30 \%$ of all pupils) and private schools (educating $7 \%$ of all pupils), because these institutions are not legally bound to teach PE as a compulsory subject (ref??). In Norway, assessment grades go towards a students' total sum of attainment grades at both 16 years $\left(10^{\text {th }}\right.$ grade) and post-18 years (upper secondary level), whilst in England assessment grades are only awarded in examinable PE. The variety of the texts and their discourses are accordingly best conceptualised as tools 'to think with', to assist the reader in interrupting taken-for-granted ideas about race and are not meant to be seen as representative of an exhaustive set of categories.

We have analysed the selected texts using a content analysis approach, informed by Fairclough's (2003) advocacy of drawing upon social theory in the analysis of texts but we have not adopted his systematic approach to linguistic discourse analysis. Acknowledging Gee's (1999) observation that critical discourse analysis is a soup composed of many different ingredients, we have thus drawn upon a range of ingredients from contemporary analyses of education and PE policy, and theoretical perspectives of race, to identify passages of text that provide insights into how, for example, students and the content of PE are racialised. We have each independently analysed the sample of documents and thereafter shared and reflected upon our interpretations, paying attention to the intertextuality of the policies. Following this shared analysis, we reanalysed the policies in the light of the emerging themes until we experienced a sense of saturation in our coding. We present the themes that have emerged below.

In keeping with the idea that research on race justifies its' knowledge production in ethical terms (Leonardo, 2013), we expect our analyses to be judged in terms of whether they enable actors to become more politically responsible subjects and to question seemingly certain relations and the social order they produce. 


\section{Emerging themes}

As a general observation, the PE policy documents in both countries are laced with ideas from the global neoliberal project of education that undermine the values of community and social justice in favour of the principles of the market economy (Evans, 2014; Rivzi and Lingard, 2010). As Kårhus (2014) demonstrates, the Norwegian school system has adapted to meet the market desires of young people who wish to develop their sporting talents. In England, as evidenced in the report 'Going the Extra Mile: Excellence in Competitive School Sport' (OfSTED, 2014), we also observe that new conservatism is traceable in contemporary PE policy (Evans, 2014), such as ideas about the character-building benefits of private schools' sports models and national 'tradition'. Clearly, these ideologies have implications for the ways in which (anti)racist curricula are conceptualised.

Though the level of the detail of attainment goals varies considerably between the national policies, the curricula for compulsory PE in Norway and England have much common content with regard to the activities deemed appropriate for cultivating healthy, active, competitive citizens. Competitive games, dance, gymnastics, outdoor life, swimming, athletics and fitness training feature strongly, similar to other countries around the world (Hardman and Marshall, 2000). Local and indigenous sports are marginalised, as they have been globally as a result of the colonial project of PE (e.g. Chepyator-Thomson, 2014; Deenan Thomson?? Australia paper??).

From our critical whiteness perspective, we can trace three main themes in the racial discourse of whiteness in PE policy that align with themes identified in critical whiteness research in pedagogy (e.g. Ladson-Billings, 2003). Firstly, whiteness is rendered invisible and constructed as a sort of neutral category that does not require naming. White experience and knowledge are universalised and taken to count for the experiences of everyone. Secondly, whiteness is constructed as normative against which ethnic minorities are measured. Certain white people and their practices are privileged and valued. Thirdly and following on from the latter, whiteness is constructed as a contingent hierarchy. We offer a number of examples from documents below and discuss more fully how these social constructs of whiteness/race exercise power in the socio-historical spaces of PE. 


\section{Whiteness as invisible, neutral, universal}

As we discussed above, whiteness is commonly found to be a racially 'unmarked' category (Frankenberg, 1993), yet its' existence is locked into the binary with the non-white Other. Hylton (2009, p.66) writes,

The 'Other' is black, peripheral, while 'white' commands the centre, owing to the 'normalisation' of whiteness. The discursive power that is embodied through the 'discourse of othering' (Riggins, 1997) causes whiteness to be 'inside', 'included', 'powerful', the 'we', the 'us', the 'answer' as opposed to the problem, and most important of all, unspoken. ... the universalisation of whiteness contributes to understanding white identity as it makes sense of 'our' news, 'our' television, important dates in 'our' calender and 'our' sport.

We might add 'our' PE curriculum to this list. These types of binaries abound in the policy documents we have analysed and are often closely linked to ideas of national identity. Norwegianness and Englishness are constituted as the neutral, normative centres of the respective country's policy. We can say that the education policies fuel ideas about the collective act of imagination and the emotional investment of belonging associated with national identities (Garner, 2010; Gullestad, 2006). Acknowledging that nations are necessarily exclusive (they exist in opposition to other nations), as Garner (2010, p. 52) underlines, "... In saying 'we', the nation simultaneously says 'they'."

Commenting upon the Norwegian core curriculum, Breidlid (2012) demonstrates how religion also plays a part of the national identity, where Christian values are conflated with universal ideas about human rights and in so doing, firmly positions non-Norwegians and peoples of other religions as Others (see italics below). The following citation from a section entitled, 'Cultural Heritage and Identity' (Utdanningsdirektoratet, n.d., pp.9-10) states:

The school system embraces many pupils from groups which in our country constitute minority cultures and languages. Education must therefore convey knowledge about other cultures and take advantage of the potential for enrichment that minority groups and Norwegians with another cultural heritage represent. ... Education should counteract prejudice and discrimination, and foster mutual respect and tolerance between groups with differing modes of life. 
Earlier in this section of the curriculum, the indigenous Sami people are given a special mention because their 'Other' cultural legacy and language " ... must be nourished so that it can grow in schools with Sami pupils, in order to strengthen Sami identity as well as our common knowledge of Sami culture." (Utdanningsdirektoratet, n.d., p.9) In other words, Sami cultural practices are confined to be taught in schools with Sami students and not seen as valued knowledge for young people with non-Sami backgrounds. The use of our in the text centralises (in)visible White Norwegian culture both in relation to both White Sami culture and non-white, Norwegian minorities.

Turning to the main purpose of PE as articulated in the Norwegian curriculum (Utdanningsdirektoratet, n.d.b, p.2), we identify the same mechanisms of power operating (see our italics):

PE ... shall inspire physical activity in all aspects of life and inspire lifelong enjoyment of being physical active. Physical activity is important for everyone as this fosters good health. The physical activity culture, such as play, sports, dance and outdoor life is part of how we establish our identity in society and what we have in common.... The social aspects of physical activities mean that PE is important for promoting fair play and respect for one another.

Unnamed White Norwegian physical activity culture is constructed as a neutral background not requiring comment. It is marked as being ours against which Other physical activity cultures can be measured. We witness traces of the Enlightenment project in ideas like 'fair play' (even though feminists have long since problematized the male, Eurocentric, colonial origins of this set of values) and (Christian) humanist ideas about respect for all. We find stronger expressions of these sentiments in the stated aims for examinable PE (Utdanningsdirektoratet, n.d. c, p. 2):

Traditional sports and newer forms of sports have always been important to Norwegian culture. A versatile use of the human body .. (is) central to national sport and outdoor traditions ...

... Teaching in the subject shall contribute to upholding and developing ethical norms and values associated with all sporting activities, and strengthen the role of sports as a standard-bearer of culture in society. (our italics)

As the White Paper (NOU, 2010:7) 'Diversity and mastery' highlights, many students from Muslim backgrounds feel positioned on the margins when religious customs concerning the body are overlooked when, for example, swimming is constructed as central to PE or 
examinable PE knowledge, although as Walseth (2015) reminds us, gender also plays a significant role.

In England, we find similar statements about the role of 'traditional' sports (rugby, cricket football, tennis, hockey, netball, rounders) as bearers of culture, constructed within a discourse of "... essential knowledge that they need to be educated citizens ... the best that has been thought and said" (Government UK, n.d., p.6) (our italics). In the recent report about good practice in PE, 'Going the Extra Mile: Excellence in Competitive School Sport' (OfSTED, 2014, p.5), the government body for inspecting the quality of education urges state schools to learn from the best practice of our elite, private schools because " ... competitive sport is part of a wider and established culture....The best state schools recognise the wider benefits of participation in competitive sport." This 'culture of competitive sports', established in the Victorian era in the elite, private boys' schools of England as part of a civilising process (Dunning, 1999), and transported around the world as an extension of nationalism and the 'Empire' (Holt, 1990), is established as a taken-for-granted part of 'our' national culture. We might ask, 'for whom is this established culture?' White, privileged males? Newly arrived immigrant students? Indeed, the PE curriculum's (Government UK, n.d.b, p.1) purpose of study states, "Opportunities to compete in sport and other activities build character and help to embed values such as fairness and respect". According to whom, and whose definitions of character, fairness, and respect underpin such an overarching aim?

\section{Whiteness as normative}

Clearly, our discussion of invisibility and universalism has already touched upon the ways in which Whiteness is constructed as normative, and illustrates how different discursive techniques of white privilege operate together to racialise actors and practices. Competitive games, as demonstrated above, are constructed as normative for 'all' English students. Similarly, in Norway, games are seen as a 'normal' activity in PE. In the description of 'Sports Activities' (Utdanningsdirektoratet, n.d.b, p.p.3) that covers a wide selection of sports, dance and alternative physical activities, dance is however positioned as off-centre in relation to normative content. It is framed to symbolise other cultures' physical activity norms (albeit in a tokenist fashion) whilst it silently reinforces valued, Norwegian normative practices like skiing and skating. At level 4, for example, students shall perform ' simple dances from 
various cultures' (p.5); at level 7 they shall 'perform simple dances from different cultures' (p.5), and at level 10, 'perform dances from other cultures'(p.6). With the exception of a competence aim at level 7 for Outdoor Life, that states 'practice some activities with roots in Sami traditions' (p.5), the learning objectives in the Norwegian PE curriculum are constructed as unnamed ethnic practices. The tokenist examples of possibilities for multicultural learning spaces for dance and outdoor life present therefore rather flat representations of people of colour contrasting with the multidimensional representations of whiteness throughout the PE curriculum (Nayak 2002).

Returning to the activities of skiing and outdoor life, it is interesting to note that within Norwegian culture their origins and cultural associations are contested. We are reminded of the social and historical processes of racialization. Historically, skiing has been an activity central to Sami culture and ways of life. Yet, following the Norwegian state's independence in 1905, skiing was adopted as a 'Norwegian' past time and sport (Goksøyr, 1994; Tordsson, 2010), and has been actively used in the creation of the national collective imagination as evidenced in the PE curriculum. Skiing is still defined as 'typically' Norwegian despite the fact that many Norwegians do not ski regularly and in particular, non-white, Norwegian youth do not identify themselves with such an activity (Andersson, 2007).

Both the English and Norwegian PE curricula also normalise the learning objective of 'health and fitness'. In the English curriculum, a main aim is to ensure that "... all pupils .... lead healthy, active lives" (Government UK, n.d.b, p.1). In the Norwegian curriculum, PE "... shall help pupils understand the ideas of an ideal body and healthy physical activity ... and ideas about health, nutrition, training and lifestyle" (p.2) We might ask, about whose ideal body are we talking? Whose healthy, active lifestyles? Whose nutritional practices? The very notion of an ideal body is moot even within limited ethnocentric perspectives (e.g. Wright and Harwood 2009), but as Azzarito (2009) warns, there is a danger that PE lessons can contributing to a recolonisation of ethnic minorities' physicality. She writes,

It is through the monocultural and ahistorical language of discourses of fatness and fitness in schools that young people's bodies, in subtle ways, are pedagogized to white ideals of the body (Azaritto 2009, p. 185). 


\section{Whiteness as a contingent hierarchy}

Turning to the third discursive technique of whiteness evident in the policies we have analysed, we see how whiteness is constructed along a hierarchy. Though inevitably interconnected to markers like social class and gender, awarding different status to different individuals and groups, whiteness is also stratified. The privilege of whiteness is not evenly distributed among white people. Above, we discussed for example the ways in which the Sami people are constructed as Other in relation to ethnic Norwegians in the core curriculum, and how Sami activities are constructed as Other in relation to unmarked Norwegian activities in the PE curriculum. There are, in fact, three additional officially reognised 'national minorities' in Norway (Gullestad, 2006) - the Finns (kvener and skogskvener), the Roma (gypsies) and the Jews - yet none of these are explicitly acknowledged in the PE policies. In both national policy contexts, there are examples of how language is used to differentiate white people's status: English and Norwegian are constructed as superior in relation to minority languages (Norway) and additional languages (England). The ability to speak several languages is not framed as an asset. Certainly, it is important to recognise that conceptualisations of bi- and trilingual students have not been static and have reflected the aforementioned historical phases of 'race' in education policy, spanning ideas of assimilation to multiculturalism, but currently we trace a deficit model of thinking with regard to nonEnglish/Norwegian speaking students, including white students. As Garner (2007) reminds us, citing Du Bois's 'wages of whiteness', historically certain groups of white people have been engaged in promoting themselves as 'whiter' than other groups. Indeed, he states,

The relationality of whiteness involves two simultaneous border maintenance processes: one between white and people of colour, and the other between white and not-quite-white. (Garner, 2007, p.175)

\section{Discussion and concluding remarks}

In our introduction, we stated that our intention with using a whiteness lens is to critique existing power relations and contribute to antiracist policy and practice in PE. We aim to shift the researcher's gaze from the Other onto the privileged and their practices that socially construct racial groups and award differential status and resources. The examples we have presented here, of which there are many more in the policies we have analysed if space were 
to allow, illustrate clearly how PE and examinable PE in Norway and England are predominantly white, unmarked spaces. The taken-for-granted physical activities that comprise much of PE's official knowledge such as team games, outdoor life/activity, swimming, and gymnastics are discursively constructed as universal and normative, as are valued practices like healthy, active lifestyles. Their cultural and social historical roots are overlooked and indeed, through the discursive construction of notions of 'fair play' as bearers of values like respect and tolerance, the power that upholds their status is obscured.

Our findings cohere with scholars' observations (e.g. McDonald, 2013; Moser, 2004) about the ways in which PE text books uphold individual, racial categories drawing mostly on discredited ideas about biological difference but also upon notions of cultural racism (i.e. that certain cultures have higher status than others) rather than challenging them. In other words, both the policy texts we have examined and the text books overlook 'race' as a system of power and instead construct it within individual terms. Students who do not conform to the normative values of a 'whitewashed' PE are 'lacking', 'deficient', and on the 'outside'. Similarly with regard to sports participation (both national curricula aim to encourage lifelong physical activity and participation in sports clubs), those who 'choose' not to participate are indirectly marginalised. The curricula do not pave the way for a critique of the processes of exnomination - the power not to be named - that is so evident.

We ask what is it like for those who are named as the Other in the white spaces of PE; those who inhabit the other side of the 'colour line' (Du Bois, 1903, cited in Garner, 2007)? Statistics concerning participation in school sports in England (ref??) and sports clubs in Norway (Strandbu and Bakken, 2007) indicate that those with black and ethnic minority backgrounds are underrepresented. Statistics of students' attainment grades in Norway (Bakken and Elstad, 2012) show that students with an ethnic minority background perform on average less well than ethnic Norwegian students. Although we cannot of course draw a direct parallel between our study and these figures, we do believe that the racialisation evident in current policy can contribute to such participation patterns and the possibility for a sense of alterity. In the absence of putting race on the educational agenda, there is a danger that stereotypes can circulate unchecked and contribute to inequitable learning environments (refs?? Students' exp of inequality due to race). 
Norway and England have strong race equality legislation with a requirement for public sector organisations, including educational policy writers, to shift the emphasis of their approach to race equality issues from a passive 'anti- discriminatory' approach, to one which actively promotes race equality and works towards changing institutional cultures and practices (e.g. CRE, 2002; BLI, 2013). Yet, there is little evidence of it being practiced in PE documents. We trace the legacies of colonialism and Eurocentric ways of reasoning, not least with regard to the spaces allocated to team games and 'character-building' practices like 'fair play'. Whiteness is 'everywhere' and 'nowhere'. Heeding Penney and Evans (1999, p. ??? see Belfast paper 2015) reminder that policies are not all encompassing or defining as they do not and cannot tell PE teachers what to do, they do nevertheless "...create the circumstances in which the range of options available are narrowed". Current policy in England and Norway favours privileged white 'racial' groups and practices traditionally associated with whiteness, discriminating those who are defined beyond these contemporary forms of racialisation. Future policy, inextricably linked to another historical and social context, has a potential to transform these social arrangements if it integrates insights from the ways in which structural racism impacts the learning opportunities for all students. Until such a time, we hope that the insights from our analysis can disturb the taken-for-granted 'racial truths' of PE educators in their enactment of existing policy.

\section{References}

Andersson, M. (2007). The relevance of the black Atlantic in contemporary sport. Racial imaginaries in Norway. International Review for the Sociology of Sport, 42(1): 65-81.

Apple, M. (2004). Ideology and Curriculum (Third Edition). London: RoutledgeFalmer. Arnot, M. (2014) Moralities and Mobilities: Sociological Perspectives on Contemporary Challenges to European Egalitarian Values in Education. Keynote presented at European Educational Research Association's annual conference, Porto, Portugal.

Azzarito, L. and Harrison, Jr, L. (2008). 'White men can't jump'. Race, gender and natural athleticism. International Review for the Sociology of Sport, 43(4): 347-364. 
Bakken, A. and Elstad, J.I. (2012). For store forventninger? Kunnskapslфftet og ulikheter $i$ grunnskolekarakterer. NOVA Rapport 7. (Too high expectations? The Quality Reform and differences in grades in primary and lower secondary schools)

Ball, S. (1993) What is policy? Texts, trajectories and toolboxes. Discourse, 13(2): 10-17.

Ball, S., Maguire, M. and Braun, A. (2012). How schools do policy. Policy enactments in secondary schools. London: Routledge.

Barker, D., Barker-Ruschti, N., Gerber, M., Gerlach, E., Sattler, S. and Pühse, U. (2014). Youths with migration backgrounds and their experiences of Physical education: an examination of three cases. Sport, Education \& Society, 19(2): 186-203.

Beidlid, H. (2012). Et ekskluderende “vi”? verdier, kulturer og kulturarv i læreplanens generelle del og i formålsparagrafen: nasjonalt felleskap, multikulturalitet og kulturell kompleksistet. Acta Didactica Norge, 6(1), Art 15. (A 'we' that excludes? Values, cultures and cultural inheritance in the national core curriculum: a national commonality, multiculturalism and cultural complexity).

BLI/ Barne-, likestilling og inkluderingsdepartement. (2013) Lov om forbud mot diskriminering på grunn av etnisitet, religion og livssyn (diskrimineringsloven om etnisitet) https://lovdata.no/dokument/NL/lov/2013-06-21-60?q=lov+om+forbud+mot+diskriminering

Bruno Massao, P. and Fasting, K. (2014). Mapping race, class and gender: experiences from black Norwegian athletes. European Journal for Sport and Society, 11(4): 331-352.

Bryan, A. (2012). 'You've got to teach people that racism is wrong and then they won't be racist': Curricular representations and young people's understandings of 'race' and racism. Journal of Curriculum Studies, 44(5): 599-629.

Chepyator-Thomson, J. R. (2014) Public policy, physical education and sport in Englishspeaking Africa. Physical Education and Sport Pedagogy, 19(5): 512-521.

CRE/Commission for Racial Equality (2002). The duty to promote race equality; a guide for further and higher education. www.cehr.gov.uk (downloaded $2^{\text {nd }}$ February 2008).

Douglas, D. and Halas, J. (2011) The wages of whiteness: confronting the nature of ivory tower racism and the implications for physical education. Sport, Education and Society, iFirst, DOI:10.1080/13573322.2011.602395. 
Dunning, E. (1999). Sport Matters. Sociological studies of sport, violence and civilization. London: Routledge.

Evans, J. (2014). Neo-liberalism and the future of a socio-educative physical education. Physical Education and Sport Pedagogy, 19(5): 545-558.

Fitzpatrick, K. (2013). Brown bodies, racialization and physical education. Sport, Education \& Society, 18(2): 135-153.

Flintoff, A. (2014) Tales from the playing field: black and minority ethnic students' experiences of physical education teacher education. Race, Ethnicity and Education, 17(3): 346-366.

Flintoff, A., Dowling, F. \& Fitzgerald, H. (2014). Working through whiteness, race and (anti)racism in physical education teacher education. Physical Education and Sport Pedagogy, http://dx.doi.org/10.1080/17408989.2014.962017.

Frankenberg, R. (1993). White Women, Race Matters: The Social Construction of Whiteness. London: Routledge.

Frankenberg, R. (1997). Introduction: Local Whiteness, Localizing Whiteness. In R. Frankenberg (Ed) Displacing Whiteness (pp. 1-34). Durham and London: Duke University Press.

Garner, S. (2007). Whiteness. An Introduction. London: Routledge.

Garner, S. (2010) Racisms. An Introduction. London: Sage Publications.

Gillborn, D. (2008). Racism and Education. Coincidence or conspiracy? London: Routledge.

Government UK (n.d.). The National Curriculum in England. Framework Document: for teaching 1 September to 31 August (2013) Government UK (n.d.)

https://www.gov.uk/government/uploads/system/uploads/attachment_data/file/339805/MAST $\underline{\text { ER_final_national_curriculum_until_sept_2015_11_9_13.pdf }}$

Government UK (n.d.b). Physical education programmes of study: key stages 1 and 2. National Curriculum in England.

https://www.gov.uk/government/uploads/system/uploads/attachment_data/file/339805/MAST $\underline{\text { ER_final_national_curriculum_until_sept_2015_11_9_13.pdf }}$ 
Gullestad, M. (2006). Plausible prejudice. Everyday experiences and social images of nation, culture and race. Oslo: Universitetsforlaget.

Hardman, K. and Marshall, J. (2000). World-wide Survey of the State and Status of School Physical Education, Final Report. Manchester : University of Manchester.

Harrison, L., Azzarito, L. and Burden, J. Jr. (2004). Perceptions of athletic superiority: a view from the other side. Race, Ethnicity and Education, 7(2):149-166.

Holt, R. (1990). Sport and the British: a Modern History (Oxford Studies in Social History). Oxford: Clarendon Press.

hooks, b. (1997) Representing Whiteness in the Black Imagination. In R. Frankenberg (Ed) Displacing Whiteness (pp. 165-179). Durham and London: Duke University Press.

Hylton, K. (2009). 'Race’ and Sport. London: Routledge.

Hylton, K. (2015). 'Race' talk! Tensions and contradictions in sport and PE. Physical Education and Sport Pedagogy. http://dx.doi.org/10.1080/17408989.2015.1043253.

Karlsen, G.E. (2002). Utdanning, styring og marked. Norsk utdanningspolitikk $i$ et internasjonalt perspektiv. Oslo: Universitetsforlaget. (Education, management and the market. Norwegian education policy in an international perspective).

Kårhus, S. (in press). Aktiv idrettsungdom: privilegerte elevgrupper i skolesystemet. I Ø. Seippel, M. K. Sisjord og Å. Strandbu (red) Ungdom og idrett. Oslo: Cappelen Damn Akademisk forlag. (Active youth: privileged students in the school system)

Kårhus, S. (2014). What limits of legitimate discourse? The case of elite sport as 'thinkable' official knowledge in the Norwegian national curriculum. Sport, Education and Society, DOI: 10.1080/13573322.2014.975112.

Leonardo, Z. (2013). The story of schooling: critical race theory and the educational racial contract. Discourse: Studies in the Cultural Politics of Education, 34(4): 599-610.

MacDonald, D., Abbott, R., Knez, K. \& Nelson, A. (2009). Taking exercise: cultural diversity and physically active lifestyles. Sport, Education \& Society, 14(1): 1-9. 
McDonald, B. (2013). The reproduction of biological 'race' through physical education textbooks and curriculum. European Physical Education Review. DOI:

$10.1177 / 1356336 \mathrm{X} 13486052$.

McEvilly, N., Verheul, M., Atencio, M. and Jess, M. (2014). Physical education for health and well-being: a discourse analysis of Scottish physical education curricular documentation. Discourse: Studies in the Cultural Politics of Education, 35(2): 278-293.

http://dx.doi.org/10.1080/01596306.2012.745736.

Moser, T. (2004). Mellom frilusftsliv og slavetrinn. Det flerkulturelle perspektivet i læremidler for kroppsøvingsfaget. I D. Skjelbred og B. Aamotsbakken (red) Seks artikler om det flerkulturelle perspektivet i læremidler. (pp. 83-116) Tønsberg, Vestfold College. http://www-bib.hive.no/tekster/hveskrift/notat/2004/notat1_2004.pdf

Nayak, A. (2002) "In Whitest England": New Subject Positions for White youth in the PostImperial Moment. In C. Livine-Rasky (ed) Working through whiteness. International perspectives. New York: State University of New York press. pp. 241-266.

Norges offentlige utredninger (NOU) (2010:7) Mangfold og mestring. Flerspråklige barn, unge og voksne i opplæringssystemet. (Diversity and mastery).

Office for Standards in Education. 2014. "Going the Extra Mile: Excellence in competitive school sport ". London: Crown Copyright.

Patton, M. Q. (1990) Qualitative Evaluation and Research Methods. (Second Edition).

London: Sage Publications.

Penney, D. and Evans, J. (1999) Politics, Policy and Practice in Physical Education. London: E \& FN Spon.

Rivzi, F. and Lingard, B. (2010). Globalizing Education Policy

Rossi, A., Tinning, R., McCuaig, L., Sirna, K. and Hunter, L. (2009). With the best intentions: a critical discourse analysis of physical education curriculum materials. Journal of Teaching in Physical Education, 28: 75-89.

Spracklen, K. (2008) The Holy Blood and the Holy Grail: Myths of scientific racism and the pursuit of excellence in sports. Leisure Studies 27(2): 221-227. 
Strandbu, Å and Bakken, A. (2007). Aktiv Oslo-ungdom. En studie av idrett, minoritets bakgrunn og kjønn. Oslo: NOVA 2007/2. (Active Oslo youth - a study of sport, ethnic minority background and gender).

Sykes, H. (2014) Un-settling sex: researcher self-reflexivity, queer theory and settler colonial studies. Qualitative Research in Sport, Exercise and Health, 6(4): 583-595.

Utdanningsdirektoratet (n.d.) Core Curriculum for Primary, Secondary and Adult Education in Norway.

http://www.udir.no/Upload/larerplaner/generell_del/5/Core_Curriculum_English.pdf

Utdanningsdirektoratet (n.d.b) Curriculum for physical education.

http://www.udir.no/k106/KRO1-03

Walseth, K. (2015). Muslim girls' experiences in physical education in Norway: What role does religiosity play? Sport, Education and Society, 20(3): 304-322. 